\title{
Uji Aktivitas Larvasida Ekstrak Etanolik Daun Serai Wangi (Cymbopogon nardus L.) terhadap Larva Culex sp. Instar III
}

\author{
Larvicidal Activitytest of Ethanolic Extract Of Citronella Grass \\ (Cymbopogon nardus L.) on Culex sp. Larvae III Instar
}

\author{
Eka Cahya Nugraha ${ }^{1}$, Tri Mulyowati ${ }^{1 *}$ dan Rinda Binugraheni ${ }^{2}$ \\ ${ }^{1}$ Program Studi D4 Analis Kesehatan \\ ${ }^{2}$ Program Studi D3 Analis Kesehatan \\ Fakultas Ilmu Kesehatan, Universitas Setia Budi Surakarta, \\ Jl. Let. Jend. Sutoyo, Mojosongo, Surakarta, 57127, Jawa Tengah, Indonesia \\ *Corresponding author: trimulyowati81@gmail.com
}

Received: Agustus 26, 2019; Revise: October 21., 2019; Accepted: November 8, 2019

DOI : https://doi.org/10.31001/biomedika.v12i2.620

\begin{abstract}
ABSTRAK
Nyamuk Culex sp. merupakan vektor filariasis. Upaya pencegahannya adalah dengan mengendalikan keberadaan nyamuk Culex sp. Serai wangi diketahui memiliki kandungan senyawa metabolit sekunder yang bermanfaat sebagai insektisida nabati. Penelitian ini dilakukan untukmengetahui daya toksisitas ekstrak etanolik daun serai wangi terhadap mortalitas larva Culex sp. instar III.Metode penelitian yang digunakan adalah metode eksperimental dengan desain penelitian rancangan acak lengkap (RAL), perlakuan yang diujikan berupa kontrol reagen; kontrol negatif; 250 ppm;353 ppm; 498 ppm; 702 ppm; 991 ppm; 1397 ppm; 1970 ppm, masing-masing diulangtiga kali. Variabel yang diamati adalah mortalitas larva pada berbagai konsentrasi. Mortalitas larva dihitung setelah 24 jam. Data yang diperoleh dianalisis menggunakan uji kruskal wallis dan uji man whitney dengan aplikasi SPSS 21 serta untuk menentukan nilai $\mathrm{LC}_{50}$ menggunakan analisis probit. Hasil penelitian menunjukkan bahwa ekstrak etanolik daun serai wangi berfungsi sebagai larvasida terhadap larva Culex sp. instar III. Semakin tinggi konsentrasi ekstrak daun serai wangi yang digunakan maka semakin besar persentase mortalitas larva Culex sp. instar III. Hasil penelitian menunjukkan bahwa konsentrasi 991 ppm merupakan konsentrasi paling efektif dan nilai $\mathrm{LC}_{50}$ adalah $1036,54 \mathrm{ppm}$. Kesimpulan penelitian ini adalah ekstak etanolik daun serai wangi (Cymbopogon nardus L.) memiliki aktivitas sebagai larvasida terhadap larva Culex sp. instar III.
\end{abstract}

Kata Kunci : aktivitas larvasida; ekstrak etanolik; daun serai wangi; mortalitas; larva Culex sp.

\begin{abstract}
Culex sp. larvae is a vector of filariasis. The prevention effort is by controlling the presence of Culex sp. Citronella grass is known to contain secondary metabolite which is useful as plant-based insecticides. This research was conducted to determine the toxicity of the ethanolic extract of citronella grass on the mortality of Culex sp. III instar.The research method used was an experimental method with a completely randomized design (CRD) research design, the treatment that was tried was reagent control; negative control; 250 ppm; 353 ppm; 498 ppm; 702 ppm; 991 ppm; 1397 ppm; 1970 ppm, three replications for each treatment. Variables observed were larvae mortality in various concentrations. Larvae mortality was calculated after 24 hours. The data obtained were analyzed using the kruskal wallis test and the man whitney test with SPSS 21 application to determine the LC 50 value using probit analysis.The results indicate that the ethanolic extract of citronella grass functioned as larvasideonCulex sp. larvae III instar. The higher the concentration of citronella grass extract used, the greater the mortality percentage of Culex sp. larvae. III instar. The concentration of 991 ppm was the most effective concentration and the LC $C_{50}$ value was 1036,54 ppm. The conclusion of this research is the ethanolic extract of citronella grass (Cymbopogonnardus L.) has larvicidal activity on Culex sp. larvae. III instar. Keywords: larvicidal activity; ethanolic extract; citronella grass; mortality; Culex sp. Larvae
\end{abstract}




\section{PENDAHULUAN}

Nyamuk merupakan serangga
yang banyak kita jumpai dan
merupakan vektor penyakit berbahaya
bagi manusia seperti filariasis, malaria
dan DBD (Susanti \& Boesri, 2012). Pestisida sintetik umumya masih digunakan untuk pengendalian nyamuk karena lebih menguntungkan, efektif, praktis dan manjur, akan tetapi apabila digunakan terus-menerus dan berulang bisa mengakibatkan lingkungan tercemar, makhluk hidup mati dan nyamuk bisa mengalami resistensi. Bahan- bahan kimia yang terkandung dalam pestisida sintetik tidak bisa terdegradasi di alam dengan sempurna mengakibatkan residu yang tertinggal bisa membuat lingkungan tercemar serta kualitas lingkungan jadi menurun. (Yunita et al, 2009).

Penularan penyakit bisa dicegah dengan cara memutus rantai penularan dengan menggunakan insektisida, pada larva nyamuk perlu dilakukan sehingga tidak menimbulkan kerugian dan tidak mencemari lingkungan serta relatif aman bagi manusia yaitu dengan cara mengoptimalkan penggunaan tumbuhan yang mempunyai kemampuan sebagai insektisida nabati. Insektisida nabati merupakan bahan alami yang bersifat mudah terurai di alam (biodegradable) sehingga tidak mencemari lingkungan dan relatif aman bagi manusia maupun ternak karena residu insektisida nabati mudah hilang. Insektisida nabati dapat dibuat dengan cara yang sederhana dan kemampuan yang terbatas. Senyawa atau ekstrak dari insektisida nabati jika digunakan di alam tidak akan mengganggu organisme lain yang bukan sasaran (Naria, 2005).

Penggunaan tanaman yang mampu menjadi insektisida nabati salah satunya adalah serai wangi. Serai wangi (Cymbopogon nardus L.) mengandung golongan senyawa flavonoid, saponin, polifenol dan minyak atsiri yang diduga senyawa-senyawaini dapat berfungsi sebagai insektisida. Minyak atsiri dalam Serai Wangi mengandung bahan aktif seperti sitronella dan geraniol dimana serangga termasuk nyamuk tidak suka dan menghindari bahan ini, jika dijadikan sebagai pengusir nyamuk penggunaan bahan-bahan ini sangat bermanfaat. (Kardinan, 2003).

Penelitian sebelumnya menggunakan daun serai wangi (Cymbopogon nardus L.) terhadapkematianlarvanyamukAedesaeg ypti yang dilakukan oleh Sefrinus et al, 2018 dari hasil penelitian diketahui bahwa kematian larva tertinggi terdapat pada konsentrasi 5000 ppm dengan persentase $100 \%$. Berdasarkan uraian tersebut maka peneliti tertarik untuk melakukan penelitian dengan judul uji aktivitas larvasida ekstrak etanolik daun serai wangi (Cymbopogon nardus L.) terhadap larva Culex sp. instar III. Penelitian ini dipilih karena belumadanya penelitian menggunakan daun serai wangi (Cymbopogon nardus L.) terhadap larva Culex sp. Alasan lain karena daun serai wangi (Cymbopogon nardus L.) mudah dibudidayakan di iklim tropis sehingga tidak sulit untuk menemukan tanaman ini.

$\begin{array}{rcr}\text { Penelitian } & \text { ini } & \text { bertujuan } \\ \text { untukmengetahui } & \text { apakah } & \text { ekstrak } \\ \text { etanolik daun serai wangi (Cymbopogon }\end{array}$


nardus L.) mempunyai aktivitas larvasida terhadap larva Culex $s p$. instar III, untuk mengetahui daya toksisitas Lethal Concentration 50\%( $\left.\mathrm{LC}_{50}\right)$ dari ekstrak etanolik daun serai wangi (Cymbopogon nardus L.)terhadap larva Culex sp. instar III.

\section{METODE PENELITIAN}

\section{Rancangan Penelitian}

Jenis penelitian yang digunakan adalah penelitian eksperimen sejati (true experiment) dengan desain acak lengkap (RAL), perlakuan yang dicoba berupa konsentrasi bertingkat. Masing-masing konsentrasi dilakukan tiga kali ulangan di Laboratorium Parasitologi.

\section{Sampel Penelitian}

Daun serai wangi yang digunakan berasal dari tanaman serai wangi(Cymbopogon nardus L.) yang tumbuh di perkebunan Universitas Negeri Tidar Magelang, Jawa Tengah.

\section{Alat Penelitian}

Penelitian ini menggunakan Alat -alat seperti oven, blender, ayakan mesh 60, neraca analitik, wadah maserasi, beaker glass, gelas ukur, labu alas bulat, timer, pipet tetes, mikropipet, tabung reaksi, rotary evaporator, alat destilasi bidwell sterling, lidi, gelas, blue tip.

\section{Bahan penelitian}

Bahan yang digunakan dalam penelitian ini antara lain ekstrak etanolik daun serai wangi, larva Culex $s p$. instar III, air, aquadest, tween 20, etanol 96\%, $\mathrm{CH}_{3} \mathrm{COOH}, \mathrm{H}_{2} \mathrm{SO}_{4}$, serbuk seng, $\mathrm{HCl} 2 \mathrm{~N}, \mathrm{HCl}$ pekat, $\mathrm{FeCl}_{3}$, xylen.

\section{Pembuatan Ekstrak Etanolik Daun Serai Wangi}

Daun serai wangi sebanyak $600 \mathrm{gr}$ dimasukkan ke dalam wadah maserasi kemudian ditambahkan pelarut etanol 96\% sebanyak 3 liter lalu ditutup rapat dan disimpan pada tempat yang terlindung dari cahaya matahari langsung. Campuran didiamkan selama 3 hari sambil dilakukan pengadukan beberapa kali, selanjutnya disaring dengan menggunakan kain dan filtrat disimpan. Ampas dimasukkan ke dalam botol maserasi dan ditambahkan pelarut etanol 96\% sebanyak 3 liter. Campuran juga didiamkan selama 3 hari sambil dilakukan pengadukan beberapa kali, selanjutnya disaring dengan menggunakan kain. Ampas dibuang dan filtrat disimpan dijadikan satu. Filtrat dimasukkan ke dalam labu alas bulat lalu diuapkan dengan rotary evaporator untuk memperoleh ekstrak kental.

Uji Fitokimia Ekstrak Etanolik Daun Serai Wangi

Identifikasi golongan senyawa kimia yang terkandung pada ekstrak daun serai wangi dilakukan dengan uji fitokimia kualitatif. Uji Flavonoid dilakukan dengan menambahkan dua ml ekstrak ditambah $2 \mathrm{ml}$ etanol $70 \%$ kemudian ditambahkan 0,05 gram serbuk seng dan $2 \mathrm{ml} \mathrm{HCl} 2 \mathrm{~N}$. Larutan didiamkan selama 1 menit kemudian ditambah dengan $2 \mathrm{ml} \mathrm{HCl}$ pekat. Hasil positif apabila terbentuk warna merah jingga atau kuning (Rumanggit et al, 2015). 
Uji Saponin dilakukan dengan menambahkan dua ml ekstrak ditambah $10 \mathrm{ml}$ aquadest panas, dikocok kuat selama 10 detik kemudian ditambah dengan beberapa tetes $\mathrm{HCl} 2 \mathrm{~N}$. Hasil positif apabila terbentuk busa stabil (Setyawati et al, 2014).

Uji Polifenol dilakukan dengan menambahkan satu gr ekstrak ditambah $1 \mathrm{ml}$ aquadest dan $2 \mathrm{ml} \mathrm{FeCl}_{3} 10 \%$. Hasil positif apabila terbentuk warna ungu, hijau, merah, biru atau hitam yang kuat (Hendrik et al, 2013).

Uji Minyak Atsiri dilakukan dengan menambahkan Larutan uji $1 \mathrm{ml}$ yang dipipet kemudian diuapkan diatas cawan porselen sampai ada endapan. Minyak atsiri dengan hasil positif jika ada bau khas yang dihasilkan oleh residu.(Agusta, 2000).

\section{Uji Aktivitas Larvasida Ekstrak Etanolik Daun Serai Wangi}

\section{(Cymbopogon nardus L.) Terhadap Larva Culex sp. Instar III}

Pembagian subjek penelitian dibagi dalam dua kelompok, yaitu kelompok perlakuan dengan pemberian ekstrak etanolik daun serai wangi (Cymbopogon nardus L.) dengan konsentrasi 250 ppm, 353 ppm, 498 ppm, 702 ppm, 991 ppm, 1397 ppm dan 1970 ppm sedangkan pada kelompok kontrol yaitu terdapat kontrol reagen (berisi larutan tween, air dan larva) dan kontrol negatif (berisi air dan larva). Gelas plastik yang berisi air $100 \mathrm{ml}$ dan masing-masing konsentrasi ekstrak etanolik daun serai wangi (Cymbopogon nardus L.) dimasukkan sebanyak masing-masing 10 larva Culex sp. instar III yang kemudian dilakukan pengamatan selama 24 jam.

Tabel 1. Variasi Konsentrasi

\begin{tabular}{lllll}
\hline $\begin{array}{c}\text { Variasi Konsentrasi } \\
(\mathbf{p p m})\end{array}$ & $\begin{array}{c}\text { Larutan Stok } \\
(\mathbf{m l})\end{array}$ & $\begin{array}{c}\text { Air } \\
(\mathbf{m l})\end{array}$ & $\begin{array}{c}\text { Larva+Air } \\
(\mathbf{m l})\end{array}$ & $\begin{array}{c}\text { Total } \\
(\mathbf{m l})\end{array}$ \\
\hline Kontrol Reagen & $\begin{array}{l}\text { Larutan Tween } \\
0,5 \mathrm{ml}\end{array}$ & 89,5 & 10 & 100 \\
\hline Kontrol Negatif & 0 & 90 & 10 & 100 \\
\hline 250 & 2,5 & 87,5 & 10 & 100 \\
\hline 353 & 3,53 & 86,47 & 10 & 100 \\
\hline 498 & 4,98 & 85,02 & 10 & 100 \\
702 & 7,02 & 82,98 & 10 & 100 \\
\hline 991 & 9,91 & 80,09 & 10 & 100 \\
\hline 1397 & 13,97 & 76,03 & 10 & 100 \\
\hline 1970 & 19,70 & 70,3 & 10 & 100 \\
\hline
\end{tabular}

\section{Analisis Data}

Data mortalitas larva Culex sp. instar III yang kemudian dilanjutkan untuk pengolahan dan analisis data menggunakan software SPSS 21 yaitu Uji
Kruskal Wallis dan Uji Man Whitney. Analisis terakhir adalah analisis probit. 


\section{HASIL dan PEMBAHASAN \\ Hasil Identifikasi Fitokimia Ekstrak Daun Serai Wangi}

Tabel 2 diatas menunjukkan bahwa ekstrak daun serai wangi positif mengandung flavonoid, saponin, polifenol, dan minyak atsiri yang telah diidentifikasi senyawa golongan secara kualitatif.

Tabel 2. Hasil Identifikasi Fitokimia

\begin{tabular}{ccc}
\hline No & Uji & Hasil \\
\hline 1 & Flavonoid & $(+)$ \\
2 & Saponin & $(+)$ \\
3 & Polifenol & $(+)$ \\
4 & Minyak & $(+)$ \\
& atsiri \\
\hline
\end{tabular}

\section{Hasil Uji Aktivitas Larvasida Ekstrak Etanolik Daun Serai Wangi (Cymbopogon nardus L.) Terhadap Larva Culex sp. Instar III}

Tabel 3 menunjukkan pada kontrol reagen, kontrol negatif dan konsentrasi 250 ppm tidak ditemukan adanya kematian larva pada semua ulangan. Rata-rata kematian larva terendah terdapat pada konsentrasi 353 ppm yaitu 0,3 (3\%) sedangkan rata-rata kematian larva tertinggi terdapat pada konsentrasi 1970 ppm yaitu 8,7 (87\%).

Tabel 3. Persentase Mortalitas Larva Culex $s p$. Instar III

\begin{tabular}{ccccccc}
\hline $\begin{array}{c}\text { Konsentrasi } \\
(\mathbf{P p m})\end{array}$ & $\begin{array}{c}\text { Jumlah } \\
\text { Larva } \\
\text { (Ekor) }\end{array}$ & \multicolumn{2}{c}{$\begin{array}{c}\text { Hasil pada Ulangan Ke- } \\
\text { (Ekor) }\end{array}$} & \multicolumn{2}{c}{$\begin{array}{c}\text { Rata-Rata } \\
\text { Kematian }\end{array}$} \\
\cline { 3 - 7 } & & I & II & III & Ekor & \% \\
\hline Kontrol Reagen & 10 & 0 & 0 & 0 & 0 & $0 \%$ \\
Kontrol Negatif & 10 & 0 & 0 & 0 & 0 & $0 \%$ \\
Ekstrak 250 & 10 & 0 & 0 & 0 & 0 & $0 \%$ \\
Ekstrak 353 & 10 & 0 & 1 & 0 & 0,3 & $3 \%$ \\
Ekstrak 498 & 10 & 1 & 1 & 1 & 1 & $10 \%$ \\
Ekstrak 702 & 10 & 3 & 3 & 4 & 3,3 & $33 \%$ \\
Ekstrak 991 & 10 & 4 & 5 & 6 & 5 & $50 \%$ \\
Ekstrak 1397 & 10 & 5 & 7 & 6 & 6 & $60 \%$ \\
Ekstrak 1970 & 10 & 7 & 10 & 9 & 8,7 & $87 \%$ \\
\hline
\end{tabular}

Gambar 1 menunjukkan adanya peningkatan persentase mortalitas larva Culex sp. instar III. Persentase mortalitas larva Culex sp. instar III meningkat sejalan dengan peningkatan konsentrasi ekstrak daun serai wangi, hal ini menunjukkan bahwa hubungan antara mortalitas larva Culex sp. instar III berbanding lurus dengan meningkatnya jumlah konsentrasi yang digunakan. Semakin tinggi konsentrasi ekstrak daun serai wangi yang digunakan maka semakin besar persentase mortalitas larva Culex $s p$. aktif yang diduga masuk ke dalam tubuh larva Culex sp. instar III. Senyawa aktif yang terdapat dalam serai 
wangi antara lain flavonoid, saponin, polifenol, dan minyak atsiri.

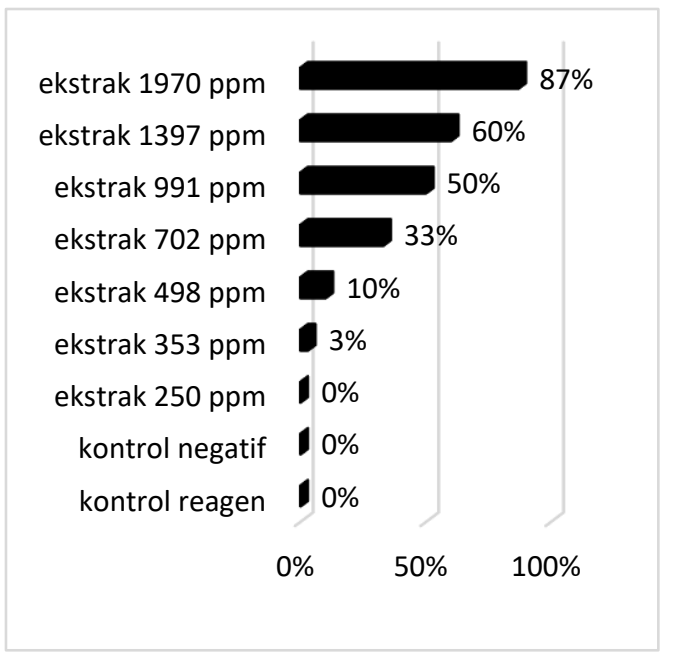

Gambar 1. Persentase Mortalitas Larva Culex sp. Instar III

Mortalitas larva Culex sp. instar III akibat perlakuan ekstrak daun serai wangi selama 24 jam mulai meningkat pada konsentrasi 353 ppm dan meningkat lagi sampai konsentrasi 1970 ppm.instar III.Mortalitas larva Culex $s p$. instar III pada berbagai konsentrasi disebabkan oleh banyaknya senyawa

\section{$\mathrm{LC}_{50}$}

$\mathrm{LC}_{50}$ merupakan suatu besaran yang diturunkan secara statistik, yang digunakan untuk menyatakan dosis atau konsentrasi tunggal suatu senyawa yang diperkirakan dapat mematikan atau menimbulkan efek toksik pada $50 \%$ hewan coba setelah perlakuan. $\mathrm{LC}_{50}$ didapatkan melalui analisis probit dan hasilnya adalah nilai LC $_{50}$ ekstrak etanolik daun serai wangi terhadap mortalitas larva Culex sp. instar III yaitu 1036,54 ppmartinya dengan konsentrasi 1036,54 ppm sudah dapat membunuh atau memberi efek toksik pada $50 \%$ hewan coba. Batas bawah yaitu 898,60 ppm dan batas atas yaitu 1195,65 ppm.

Tabel 5. Hasil Analis Probit

\begin{tabular}{ccc}
\hline LC & Hasil $(\mathrm{ppm})$ & SD $(\mathrm{ppm})$ \\
\hline 10 & 457,78 & $342,80-611,32$ \\
\hline 20 & 606,14 & $488,43-752,21$ \\
\hline 30 & 742,13 & $624,40-882,10$ \\
\hline 40 & 882,15 & $760,23-123,62$ \\
\hline 50 & 1036,54 & $898,60-1195,65$ \\
\hline 60 & 1217,94 & $1043,31-1421,81$ \\
\hline 70 & 1447,74 & $1205,14-1739,20$ \\
\hline 80 & 1772,55 & $1408,96-2229,97$ \\
\hline 90 & 2347,02 & $1730,31-3183.53$ \\
\hline 99 & 4569,93 & $2764,70-7553,94$ \\
\hline
\end{tabular}

\section{Hasil Analisis Data}

Untuk mengetahui kebermaknaan uji aktivitas larvasida ekstrak etanolik daun serai wangi (Cymbopogon nardus L.) terhadap larva Culex sp. instar III apabila dibandingkan dengan kontrol dilakukan uji statistik Kruskal Wallis didapatkan hasil nilai $\mathrm{p}<0,05(\mathrm{p}=0,002)$ dimana ada perbedaan yang bermakna antara kelompok kontrol dan kelompok perlakukan secara kesuluruhan. Selanjutnya dilakukan uji statistik Mann Withney, dikatakan bermakna apabila nilai $\mathrm{p}<0,05$ artinya terdapat perbedaan signifikan sedangkan apabila nilai $\mathrm{p}$ $>0,05$ artinya tidak terdapat perbedaan signifikan. Hasil uji Man Whitney yang membandingkan tiga konsentrasi tertinggi menunjukkan nilai $\mathrm{p}>0,05$ artinya tidak terdapat perbedaan yang signifikan. Mengacu dari hasil uji Man Whitney, apabila diantara tiga konsentrasi tertinggi tidak terdapat perbedaan yang signifikan maka diambil konsentrasi terendah sebagai konsentrasi yang efektif. Suatu 
konsentrasi dapat dikatakan efektif apabila dengan konsentrasi terendah dapat membunuh hewan uji sebanyakbanyaknya. Konsentrasi 991 ppm ditetapkan sebagai konsentrasi paling efektif karena dapat membunuh lima dari sepuluh larva uji atau 50\% rata-rata kematian larva uji.

sehingga menurunkan produksi ATP dan mengurangi penggunaan $\mathrm{O}_{2}$ sehingga proses metabolisme makanan terhambat. Penghambatan metabolism menyebabkan terjadinya pengendapan berbagai senyawa pada usus larva, sehingga lumen perut menjadi meningkat (hipertonis) menyebabkan air dari luar usus masuk melalui proses osmosis, dan menyebabkan usus menjadi bengkak dan akhirnya lisis serta rusak sehingga perut menjadi lumpuh dan nyamuk berhenti makan (Siskaet al, 2018).

Penelitian sebelumnya menjelaskan polifenol dan saponin bisa menghambat atau bahkan bisa membunuh stadium larva nyamuk (Hastuti,2008). Saponin diketahui bisa merusak membran sel, menyebabkan terganggunya proses metabolisme di dalam serangga dan polifenol berfungsi sebagai inhibitor di dalam pencernaan serangga. Menurut hasil penelitian Suparjo th 2008 juga membuktikan bahwa Saponin mempunyai efek anti jamur dan anti serangga. (Polifenol merupakan senyawa yang bersifat sebagai inhibitor pencernaan (Atmowidi, 2003). serangga yang memakan polifenol akan menurunkan
Senyawa aktif yang terdapat dalam serai wangi antara lain flavonoid, saponin, polifenol, dan minyak atsiri. Senyawa golongan flavonoid memiliki aktivitas larvasida yaitu dapat mengganggu fungsi mitokondria khususnya reaksi transfer electron

kemampuan serangga dalam mencerna makanan (Nursal et al, 2003). Ekstrak etanolik daun serai wangi yang mengandung saponin dan polifenol sebagai racun perut dan racun pernafasan sehingga bisa masuk ke tubuh larva nyamuk Culex melalui mulut larva (termakan larva) dan bisa meracuni larva culex, sebagai racun pernafasan zat dalam ekstrak akan meracuni larva culex yang melalui saluran pernafasan larva di permukaan tubuh larva kemudian masuk ke dalam tubuh larva (Aminah et al, 2001). Serai wangi juga mengandung senyawa aktif minyak atsiri, sifat lipofilik minyak memudahkannya untuk mengganggu fungsi metabolisme, biokimia, fisiologis, morfologi dan perilaku serangga (Rocha et al, 2015).

\section{KESIMPULAN}

Ekstrak etanolik daun serai wangi mempunyai aktivitas larvasida terhadap mortalitas larva Culex $s p$. instar III. Daya toksisitas LC 50 ekstrak etanolik daun serai wangi terhadap mortalitas larva Culex sp. instar III adalah 1036,54 ppm. 


\section{DAFTAR PUSTAKA}

Agusta, A. 2000. Minyak Atsiri Tumbuhan Tropika Indonesia. Bandung: Penerbit ITB.

Aminah, ST., Sigit, S., Partosoedjono, S. \& Chairul. 2001. S. larak, D.metel, dan E. prostata sebagai Larvasida Aedes aegypti. Cermin Dunia Kedokteran. No. 131. Hal : $7-9$.

Atmowidi, T. 2003. Mengapa ditemukan Anomali Keragaman pada Serangga. Makalah Falsafah Sains. 13 November 2003. Bogor : Institut Pertanian Bogor.

Hastuti, H. 2008. Daya Bunuh Ekstrak Daun Pandan Wangi (Pandanus amaryllifolius Roxb.) terhadap Larva Anopheles aconitus Donitz. [Skripsi]. Surakarta: Fakultas Kedokteran UNS.

Hendrik, W., Erwin, \& Panggabean, A., Sentosa. 2013. Pemanfaatan Tumbuhan Serai Wangi (Cymbopogon nardus (L.) Rendle) sebagai Antioksidan Alami. Jurnal Kimia Mulawarman, 10(2), 7479.

Kardinan, A. 2003. Pestisida Nabati Ramuan dan Aplikasinya. Jakarta: Penebar Swadaya.

Naria, E. 2005. Insektisida Nabati untuk Rumah Tangga. Info Kesehatan Masyarakat, 9(1), 28-32

Nursal, Pasaribu, N. 2003. Indeks Nutrisi Larva Instar V Heliothis Armigera Hubner pada Makanan yang Mengandung Ekstrak Kulit Batang Bakau (Rhizopora Mucronata Lamk.) dan Temperatur yang Berbeda. Diakses tanggal 16 Juli 2019. http://library.usu.ac.id/download/fmipa/b iologi-nursal.pdf

Rocha, D., Olivia, M., Maria, T., Ana, C., Manuel, D., Chtistina, M. 2015.

Larvacidal activity against Aedes aegypti of Foeniculum vulgar essential oils from Portugal and Cape Verde. Nat Prod Commun, 10(4), 1-7, doi: 10.5376/jmr.2015.05.0019.

Rumanggit, Hanna, M., Max, J., Runtuwene, \& Sri, Sudewi. 2015. Uji Fitokimia dan Uji Aktivitas Antioksidan dari Ekstrak Etanol Spons Lamellodysidea herbacea. Jurnal Ilmiah Farmasi, 4(3), 183-189.

Setyawati, W.,A.,E., Ariani, S.,R.,D., Ashadi, Mulyani, B., \& Rahmawati, C.,P. 2014.

Siska, N.K, Budianto, B.H., \& Basuki, E. 2018. Stidu Toksisitas: Ekstrak Metanol Bonggol Pisang Ambon (Musa acuminata L. Cv. Gros Michel) terhadap Aedes aegypti (Diptera: Culcidae). Aspirator, 10(2), 93-102.

Suparjo. 2008. Saponin, Peran dan Pengaruhnya bagi Ternak dan Manusia. [Karya Tulis Ilmiah]. Jambi: Fakultas Peternakan Universitas Jambi.

Susanti, L., \& Boesri, H. 2012. Toksisitas Biolarvasida Ekstrak Tembakau Dibandingkan dengan Ekstrak Zodia terhadap Jentik Vektor Demam Berdarah Dengue.Buletin Penelitian Kesehatan, 40(2), 75-85.

Yunita, E., Suprapti, N., \& Hidayat, J. 2009. Pengaruh Ekstrak Daun Teklan (Eupatorium riparium) terhadap Mortalitas dan Perkembangan Larva Aedes aegypti. Bioma, 11(1), 11-17. 